\title{
The Impact of Microfinance: Helping to Improve Donor Effectiveness in Microfinance
}

\author{
Shivaprasad G. ${ }^{1 *}$ and K.H Anilkumar ${ }^{2}$ \\ ${ }^{1}$ ABBS School of Management, Off Magadi Road, Andrahalli Main Road, Bangalore, Karnataka, India \\ ${ }^{2}$ Karnataka College of Management, Bangalore, India \\ *Corresponding author: shivaprasad.g@acharyabbs.ac.in
}

\begin{abstract}
Microfinance as a financial tool has also seen ups and downs. During 2011, market commentators predicted the end of India's microfinance market but as on 31 March 2014, there were more than 74.30 lakh savings-linked SHGs, covering over 9.7 crore poor households. The total savings of these SHGs with banks amounted to ₹ 9897.42 crore. The number of credit-linked SHGs under the programme was 41.97 lakh. In 2011, the government of the state of Andhra Pradesh was seeking to prohibit the microloans business. After the crisis, RBI has handled the sector very vigilantly, carefully and very thoughtfully. The National Bank continued to provide 100 per cent refinance assistance to banks for financing SHGs. The SHG-Bank Linkage Programme (SHG-BLP) has expanded substantially since it was first launched on a pilot scale in 1992. The geographical spread of the movement has also been quite impressive from an essentially Andhra Pradesh - Karnataka phenomenon in the beginning now spreading to even the most remote corners of India. This paper tries to address impact of microfinance on women self help group members in comparison with non-beneficiaries of the microfinance schemes. Study found that the impact of microfinance on rural women economic condition is positive and microfinance is reforming their life.
\end{abstract}

Keywords: Microfinance, economic, SHGs, Empowerment, Rural Women, Beneficiaries, food expenditure, personal expenditure and investment

The status of women in India has seen two ends of the spectrum, from being one of equality and respect to being the disadvantaged populace in the recent times. Over the past millennium, the status of women in India has been subject to a great number of changes. Since independence women's right are secured under the constitution of India. Equality, dignity and freedom from discrimination are ensured and further many statutes are in place governing the rights of women. Though the status of women has alleviated through the times in terms of social and economic emancipation, Indian women have a long way to go. It is not only the rural women who tend to lack the opportunities to improve their lives but also women in the urban areas too, though their condition is better than the rural women are. In this scenario, any effort to bring the women out of their vicious cycle of poverty that not only impoverishes them but also demoralizes them needs to be welcomed. Such efforts at the social and economic improvement of the women of India will go a long in not only improving the status of the women but a better nation as well.

\section{REVIEW OF LITERATURE}

\section{Microfinance Impact at the Individual Level}

Reviews of microfinance efforts (Morduch, Haley, 2001), from various parts of the world suggests that, by and large, access to microfinance has had a positive economic impact, that this impact has been often larger for those closer to the poverty line than those further away and that they increase with duration of membership or intensity of loans as members begin to invest in assets rather than consumption. The economic impact is visible in terms of savings habit, increased credit accessibility, 
contribution to household income, and acquisition of household assets (E.M. Reji, 2009). The 'wider impacts' of micro-lending on the lives of the poor aim at gauging the social impact analyses of microfinance programs. This wider impact can be taken to be a 'public good' that benefits the sector the microfinance institutions (MFIs), donors, borrowers, and even the non-borrowers, in its entirety (Asad Ghalib, 2009).

There is a high correlation between microcredit and children's education (Yasmine F. Nader, 2008), also income and assets. It has also been proved in various studies that microcredit has improved the health and harmony in the family that has taken the credit. The net impact not only in case of all the borrowers but also in case of the poorest borrowers, shows that the better outreach of the bank linkage programme of borrowing on income is positive. However, certain shortcomings were also observed in some studies. The process of empowerment was poor (K. Sivachithappa, 2013), although a positive impact on poverty was observed.

\section{Microfinance Impact at the Household Level}

The empowerment of women through SHGs would lead benefits not only to the individual women but also for the family and community as whole through collection action for development these SHGs have collection action (A. Angel Anila, 2012). Microfinance through SHG seems to be a unique action oriented rural development strategy to tap the gesture for the up-liftment in social and economic point of view (Mula G. \& Sarker S.C. 2013). The net effect of microfinance on few household durable items like fan, bicycle and sewing machine, of the poor borrowers was found to be positive while the net effect of microfinance on household's durables of the non-poor borrowers was marginal'. The majority of the poor non-borrowers reported no change in their livestock compared to the poor borrowers (Nasim Shah Shirazi, 2012).

\section{Research Gap and Research Questions}

The extensive study of existing literature indicates that several studies have been undertaken either by individuals, institutions or research agencies to review the prospects of the microfinance and socio-economic status of women. Though the agencies examined the socio-economic impact of the programme, they were not comprehensive and complete in their approach. As a matter of fact, contributions made in this regard by individual academicians and researchers are limited in scope. Further, no study was conducted in Malenadu regions in linking credit with economic conditions of women SHGs in the region. To fill the gap in research, the present study has been undertaken.

This study will try to address several questions raised by the past studies i.e., How does microfinance affect economic conditions of women microfinance beneficiaries compare to non-beneficiaries of microfinance in terms of Income, savings, expenditure, education and investment on fixed assets and live stocks of the beneficiaries?

\section{Objectives of the Research}

The specific objectives of the present study is to assess the reformative role of microfinance on economic conditions of the women Self Help Group members and compare economic conditions of beneficiaries with the non-beneficiaries of microfinance.

\section{Hypothesis}

"The economic conditions of SHGs largely depend upon the nature of the benefit received when compared with SHGs not receiving any benefits."

$\mathbf{H}_{\mathbf{o}}$ : There is no significant difference in the economic conditions of beneficiaries and nonbeneficiaries during pre and post Microfinance period.

$\square \mathbf{H}_{\mathbf{a}}$ : There is a significant difference in the economic conditions of beneficiaries and nonbeneficiaries during pre and post Microfinance period.

\section{Type of Research}

Descriptive (Ex post facto research- Pre and post Microfinance)

\section{Sources of Data Collection}

Primary Data-structured questionnaire interview Secondary Data-NABARD, APEX, CESS, SERP etc. 


\section{Validity}

Study is based on Extensive review of literature - Alreck \& Settle, 1995; Gaddis, 1998; Long, 1998; and Leedy \& Ormrod, 2001).

$\square$ Drafted 22 items, 6 content judges and the final scale comprised of 15 items.

\section{Reliability}

Cronbach's Alpha is 0.738 (number of items 15) which is acceptable (Cronbach, 1951; Nunnally \& Bernstein, 1994 and George and Mallery, 2003).

\section{Normality}

The Shapiro-Wilk Test shows that $p$ value is more than the alpha value in each factor, it can be understood that data came from a normally distributed population.

\section{Economic Indicators}

Income, Savings, Food Expenditure, Personal Expense, Education, Investments on Fixed Assets \& Livestock and Home Appliances.

\section{Tools of Analysis}

Paired sample T-test

\section{Data Analysis and Elucidation}

\section{Profile of Women Respondents}

Profile of women respondents is given in this section. The analysis is based on the data collected from 800 beneficiaries and 200 non-beneficiaries from the Malenadu region of Karnataka State. In order to evaluate the impact of microfinance programme on the women self-help group, it is necessary to know about their demographic background. This helps to identify the factors that led to the successor or otherwise of the enterprises undertaken by them. The demographic profile of the respondents in respect of their religion, age case, literacy level, marital status, size of the family and primary occupation are focused.

The following text and tables relevant shows the independent variables and their distribution, which will form an integral part of data analysis and help us draw further insights and inferences from the data especially when combined and cross-tabulated with dependant variables (various economic, social, and socio-economic factors and indicators).

\section{Distribution of Women Respondents}

Table 1 provides distribution of women beneficiaries and non-beneficiaries of microfinance programme in Malenadu region.

Table 1: Distribution of Women Beneficiaries and Non-Beneficiaries of Microfinance Programme in Malenadu Region

\begin{tabular}{ccccc}
\hline $\begin{array}{c}\text { Period of } \\
\text { Association \& } \\
\begin{array}{c}\text { Approached for } \\
\text { Microfinance }\end{array}\end{array}$ & $\begin{array}{c}\text { Benefi- } \\
\text { ciaries }\end{array}$ & $\begin{array}{c}\text { \% to } \\
\text { Total }\end{array}$ & $\begin{array}{c}\text { Non-bene- } \\
\text { ficiaries }\end{array}$ & $\begin{array}{c}\text { \% to } \\
\text { Total }\end{array}$ \\
\hline 1996-2000 & 200 & 25 & 50 & 25 \\
$2001-2005$ & 200 & 25 & 50 & 25 \\
$2006-2010$ & 200 & 25 & 50 & 25 \\
2011 onwards & 200 & 25 & 50 & 25 \\
\hline Total & $\mathbf{8 0 0}$ & $\mathbf{1 0 0}$ & $\mathbf{2 0 0}$ & $\mathbf{1 0 0}$ \\
\hline
\end{tabular}

Source: Field survey.

Table 1 shows the distribution of the beneficiaries and non-beneficiaries. The study has been conducted by taking 200 beneficiary members and 50 non-beneficiary members from each period of association, which is grouped in periods of 5 years. The total sample comprises 800 members and 200 non-members and the total sample members and non-members are 1000. Members and non-members are distributed equally.

\section{Religion}

Table 2 presents the religion-wise distribution of respondents in the study area.

Table 2: Religion-Wise Distribution of Sample Respondents

\begin{tabular}{ccccc}
\hline Religion & $\begin{array}{c}\text { Beneficia- } \\
\text { ries }\end{array}$ & \% to total & $\begin{array}{c}\text { Non-Benefi- } \\
\text { ciaries }\end{array}$ & $\begin{array}{c}\text { \% to } \\
\text { total }\end{array}$ \\
\hline Hindu & 657 & 82.125 & 169 & 84.5 \\
Muslim & 76 & 9.5 & 14 & 7 \\
Christian & 58 & 7.25 & 14 & 7 \\
Others & 9 & 1.125 & 3 & 1.5 \\
\hline Total & $\mathbf{8 0 0}$ & $\mathbf{1 0 0}$ & $\mathbf{2 0 0}$ & $\mathbf{1 0 0}$ \\
\hline
\end{tabular}

Source: Field survey. 
Table 2 shows that, out of 800 beneficiaries, 657 respondents (82.125 per cent) were Hindus, 76 (9.5 per cent) were Muslims whereas 58 (7.25 per cent) were Christians while 9 (1.125 per cent) belonged to different religions. Non-beneficiaries were distributed with 169 (84.5 per cent) being Hindus, 14 (7 per cent) Muslims while 14 (7 per cent) Christians whereas a small number 3 (1.5 per cent) belonged to different religions.

\section{Community}

Community plays an important role in India with special statuses to scheduled castes and other reserved categories. In order to uplift the community, government has packages and allocated further rights to these which will enable them to come up in life, both economically and socially.

Table 3: Community-wise Classification of Respondents

\begin{tabular}{ccccc}
\hline Caste & $\begin{array}{c}\text { Beneficia- } \\
\text { ries }\end{array}$ & \% to Total & $\begin{array}{c}\text { Non-bene- } \\
\text { ficiaries }\end{array}$ & \% to Total \\
\hline SC & 101 & 12.625 & 20 & 10 \\
ST & 213 & 26.625 & 53 & 26.5 \\
OBC & 370 & 46.25 & 94 & 47 \\
GM & 53 & 6.625 & 23 & 11.5 \\
Others & 63 & 7.875 & 10 & 5 \\
\hline Total & $\mathbf{8 0 0}$ & $\mathbf{1 0 0}$ & $\mathbf{2 0 0}$ & $\mathbf{1 0 0}$ \\
\hline
\end{tabular}

Source: Field survey.

It is observed from the Table 3 that out of 800 beneficiaries 101 (12.625 per cent) were SC caste, 213 (26.625 per cent) were ST, 370 (46.25 per cent) were OBC, 53 (6.625 per cent) were GM and 63 (7.875 per cent) were from other caste. Out of 200 non-beneficiaries, 20 (10 per cent) were SC, 53 (26.5 per cent) were ST, 94 (47 per cent) were OBC, 23 (11.5 per cent) were GM and 10 (5 per cent) were from other caste.

\section{Age of the Respondents}

Age is an important factor to make any programme success. Here also, the age factor plays an important role in participating income-generating activities. The total respondents are classified into four age groups and the details are presented in Table 4.
Table 4: Age-wise Categorization of Respondents

\begin{tabular}{ccccc}
\hline $\begin{array}{c}\text { Age } \\
\text { Group }\end{array}$ & $\begin{array}{c}\text { Beneficia- } \\
\text { ries }\end{array}$ & $\begin{array}{c}\text { \% to } \\
\text { Total }\end{array}$ & $\begin{array}{c}\text { Non-benefi- } \\
\text { ciaries }\end{array}$ & $\begin{array}{c}\text { \% to } \\
\text { Total }\end{array}$ \\
\hline Below 25 & 20 & 2.5 & 3 & 1.5 \\
$26-35$ & 184 & 23 & 33 & 16.5 \\
$36-45$ & 376 & 47 & 96 & 48 \\
46 \& above & 220 & 27.5 & 68 & 34 \\
\hline Total & $\mathbf{8 0 0}$ & $\mathbf{1 0 0}$ & $\mathbf{2 0 0}$ & $\mathbf{1 0 0}$ \\
\hline
\end{tabular}

Source: Field survey.

Evidently, a majority of the beneficiaries (47 per cent) and non-beneficiaries (48 per cent) were found in the age group of 36-45 years. It may be inferred that majority of respondents were clustered in the productive years.

\section{Educational Background}

Details of the respondents, according to their educational levels are presented in Table 5.

Table 5: Level of Education-wise Segregation of Respondents

\begin{tabular}{ccccc}
\hline $\begin{array}{c}\text { Education- } \\
\text { al Level }\end{array}$ & $\begin{array}{c}\text { Beneficia- } \\
\text { ries }\end{array}$ & $\begin{array}{c}\text { \% to } \\
\text { Total }\end{array}$ & $\begin{array}{c}\text { Non-bene- } \\
\text { ficiaries }\end{array}$ & $\begin{array}{c}\text { \% to } \\
\text { Total }\end{array}$ \\
\hline Illiterates & 284 & 35.5 & 50 & 25 \\
Primary & 236 & 29.5 & 92 & 46 \\
Middle & 127 & 15.9 & 34 & 17 \\
$\begin{array}{c}\text { School } \\
\text { Pre- }\end{array}$ & 88 & 11.0 & 15 & 7.5 \\
$\begin{array}{c}\text { University } \\
\text { Degree \& } \\
\text { above }\end{array}$ & 65 & 8.1 & 9 & 4.5 \\
\hline Total & 800 & $\mathbf{1 0 0}$ & $\mathbf{2 0 0}$ & $\mathbf{1 0 0}$ \\
\hline
\end{tabular}

Source: Field survey.

It is noticed from the Table 5 that the illiterates are found more in numbers in case of beneficiaries rather than non-beneficiaries as the percentage is 35.5 per cent. It is concluded from the Table 5 that the illiterates were attracted much towards microfinance to improve their standard of living instead of literates whose percentage is very less as noticed from the data incorporated in the Table.

\section{Marital Status}

Marital status of respondents is presented in Table 6. As it is observed from the table, it reveals that most of the sample respondents were married 
constituting 93 per cent among the beneficiaries and 94.5 per cent among non-beneficiaries.

Table 6: Marital Status of Respondents

\begin{tabular}{ccccc}
\hline $\begin{array}{c}\text { Marital } \\
\text { Status }\end{array}$ & $\begin{array}{c}\text { Beneficia- } \\
\text { ries }\end{array}$ & $\begin{array}{c}\text { \% to } \\
\text { Total }\end{array}$ & $\begin{array}{c}\text { Non-benefi- } \\
\text { ciaries }\end{array}$ & $\begin{array}{c}\text { \% to } \\
\text { Total }\end{array}$ \\
\hline Married & 744 & 93 & 189 & 94.5 \\
$\begin{array}{c}\text { Un- } \\
\text { married }\end{array}$ & 25 & 3.125 & 6 & 3 \\
Divorcee & 10 & 1.25 & 0 & 0 \\
Widow & 21 & 2.625 & 5 & 2.5 \\
\hline Total & $\mathbf{8 0 0}$ & $\mathbf{1 0 0}$ & $\mathbf{2 0 0}$ & $\mathbf{1 0 0}$ \\
\hline
\end{tabular}

Source: Field survey.

The Un-married and divorced women are negligible percentage among the respondents. It may be concluded that more than 93 per cent of the sample respondents were married both among beneficiaries and non-beneficiaries.

\section{Size of Family}

The number of persons living in respondent's house in the Malenadu region is presented in Table 7.

Table 7: Family Size of the Respondents

\begin{tabular}{ccccc}
\hline $\begin{array}{c}\text { Family } \\
\text { Size }\end{array}$ & $\begin{array}{c}\text { Benefi- } \\
\text { ciaries }\end{array}$ & \% to Total & $\begin{array}{c}\text { Non-bene- } \\
\text { ficiaries }\end{array}$ & to Total \\
\hline $1-4$ & 426 & 53.25 & 25 & 12.5 \\
$5-7$ & 128 & 16 & 115 & 57.5 \\
$8-10$ & 188 & 23.5 & 44 & 22 \\
$11 \&$ above & 58 & 7.25 & 16 & 8 \\
\hline Total & $\mathbf{8 0 0}$ & $\mathbf{1 0 0}$ & $\mathbf{2 0 0}$ & $\mathbf{1 0 0}$ \\
\hline
\end{tabular}

Source: Field survey.

The table 7 reveals that 53.25 per cent of the households are in the size of $1-4$ members, followed by 16 per cent in the size of $5-7$ and 23.5 per cent in the size of 8-10. The family size of 11 members and above constituted just 7.25 per cent. Evidently, the beneficiaries have strictly followed the family planning methods confining their family size to 1 to 4 members only, because of greater awareness among the beneficiaries. But in the case of nonbeneficiaries only 12.5 per cent of families are in the size of 1-4 members. It is clear that those who joined microfinance programme are more conscious about the family planning than the non-beneficiaries.

\section{Occupational Pattern}

Occupational distribution of the respondents is presented in Table 8.

Table 8: Occupational Pattern among Respondents

\begin{tabular}{ccccc}
\hline Occupation & $\begin{array}{c}\text { Benefi- } \\
\text { ciaries }\end{array}$ & $\begin{array}{c}\text { \% to } \\
\text { Total }\end{array}$ & $\begin{array}{c}\text { Non-bene- } \\
\text { ficiaries }\end{array}$ & $\begin{array}{c}\text { \% to } \\
\text { Total }\end{array}$ \\
\hline $\begin{array}{c}\text { Agriculture/ } \\
\text { Cultivators }\end{array}$ & 377 & 47.125 & 30 & 15 \\
$\begin{array}{c}\text { Agricultural } \\
\text { Labourers } \\
\text { Non- }\end{array}$ & 175 & 21.875 & 58 & 29 \\
$\begin{array}{c}\text { Agriculture/ } \\
\text { Others }\end{array}$ & 248 & 31 & 112 & 56 \\
\hline Total & $\mathbf{8 0 0}$ & $\mathbf{1 0 0}$ & $\mathbf{2 0 0}$ & $\mathbf{1 0 0}$ \\
\hline
\end{tabular}

Source: Field survey.

The occupational pattern shows that agriculture is the main occupation of the beneficiary respondents. Agriculture is the predominant sector for microfinance beneficiaries of the Malenadu region, which employs nearly 47.125 per cent of the total respondents. The rest of the labour force is engaged in other sectors. But where is in the case of nonbeneficiaries only 15 per cent of the respondents were depending on the agricultural activities and more number of respondents i.e. 47.125 per cent depends on the agricultural labourer activities. So income generation of the non-beneficiaries is purely depends on number of working days available in the Malenadu region.

With the analysis of independent variables in the previous section it is now to see how the dependent variables are distributed and their status, which will then be cross tabulated with the independent variables which will answer few important questions by giving further insights into the study and a better understanding. The objective is to understand the economic conditions of women SHGs members and how micro-finance has impacted (whether positively or negatively) their status.

It is a good place now to mention the hypothesis, which forms base for the data analysis.

\section{Comparative Analysis of Income Level of Beneficiaries and Non-Beneficiaries}

To find out the difference in average annual income of the beneficiaries with the non-beneficiaries 
of microfinance in the various periods, the total beneficiaries and non-beneficiaries were broadly classified into four groups viz., (1) 1996-2000 (2) 2001-2005 (3) 2006-2010 and (4) 2011 onwards.

Table 9: Income Level

\begin{tabular}{ccc}
\hline Income Level & Beneficiaries & Non-Beneficiaries \\
\hline $2000-11999$ & 3 & 136 \\
$12000-21999$ & 38 & 64 \\
$22000-31999$ & 225 & - \\
$32000-41999$ & 224 & - \\
$42000-51999$ & 93 & - \\
$52000-61999$ & 114 & - \\
$62000-71999$ & 49 & - \\
$72000-81999$ & 20 & - \\
$82000-91999$ & 23 & - \\
$92000-101999$ & 11 & - \\
Grand Total & 800 & $\mathbf{2 0 0}$ \\
\hline
\end{tabular}

Source: Field Survey.

Table 9 reveals the income level of beneficiaries and non-beneficiaries during pre and post period of microfinance in Malenadu region.
The calculated $t$ values of pre and post microfinance period of the respondent beneficiaries of all the period of association are significant at 5 per cent level, but it is insignificant in case of nonbeneficiaries who approached for microfinance after 2011. It is clear from the table 10 that the average annual income generation among the various period of association and approached (non-association) during the pre-period constituted $₹ 9883.40$ and $₹ 10106.50$ in case of beneficiaries and non-beneficiaries respectively which rose to ₹ 42089.00 and $₹ 11559.50$ in post period which clearly indicates that there is remarkable improvement in the income generation of microfinance beneficiaries.

It is evident from the table 10 that the difference in income level during pre-microfinance period in case of beneficiaries and non-beneficiaries is very negligible comparatively with post- microfinance period where the percentage increase in the average annual income of the beneficiaries during post microfinance is 17.60 per cent. But it is just 1.13 per cent with regard to non-beneficiaries. It is also noticed that the clients who joined the microfinance scheme during 1996-2000 had very low income compared to other time period of association i.e. only ₹ 7711.00. But after availing microfinance, beneficiaries who joined the scheme during 1996-

Table 10: Average Annual Income of the Respondents

\begin{tabular}{|c|c|c|c|c|c|c|c|}
\hline \multicolumn{8}{|c|}{ Beneficiaries } \\
\hline $\begin{array}{c}\text { Period of } \\
\text { Association }\end{array}$ & Respondents & $\begin{array}{l}\text { Pre } \\
\text { Average Annual } \\
\text { Income }\end{array}$ & $\begin{array}{l}\text { Post Average } \\
\text { Annual Income }\end{array}$ & $\begin{array}{l}\text { Incremental } \\
\text { Income }\end{array}$ & CAGR \% & $\begin{array}{l}\text { Paired } \\
\text { t-value }\end{array}$ & $\begin{array}{l}\text { Sig. (2 } \\
\text { tailed) }\end{array}$ \\
\hline $1996-2000$ & 200 & 7711.00 & 57672.50 & 49961.50 & 11.82 & -32.68 & $.000^{*}$ \\
\hline 2001-2005 & 200 & 9105.50 & 45483.00 & 36377.50 & 14.19 & -44.19 & $.000^{*}$ \\
\hline 2006-2010 & 200 & 10697.00 & 36449.50 & 25752.50 & 17.80 & -37.63 & $.000^{*}$ \\
\hline 2011 Onwards & 200 & 12020.00 & 28751.00 & 16731.00 & 26.61 & -31.88 & $.000^{*}$ \\
\hline Total & 800 & 9883.40 & 42089.00 & 32205.60 & 17.60 & -49.34 & $.000^{*}$ \\
\hline \multicolumn{8}{|c|}{ Non-Beneficiaries } \\
\hline $\begin{array}{l}\text { Approached for } \\
\text { Microfinance } \\
\text { (Non-Association) }\end{array}$ & Respondents & $\begin{array}{c}\text { Pre } \\
\text { Average Annual } \\
\text { Income }\end{array}$ & $\begin{array}{l}\text { Present Average } \\
\text { Annual Income }\end{array}$ & $\begin{array}{l}\text { Incremental } \\
\text { Income }\end{array}$ & $\begin{array}{c}\text { CAGR } \\
\%\end{array}$ & $\begin{array}{l}\text { Paired } \\
\text { t-value }\end{array}$ & $\begin{array}{l}\text { Sig. (2 } \\
\text { tailed) }\end{array}$ \\
\hline $1996-2000$ & 50 & 7649.80 & 12473.80 & 4824.00 & 3.11 & -42.17 & $.000^{*}$ \\
\hline 2001-2005 & 50 & 9643.40 & 10072.00 & 428.60 & 0.43 & -2.72 & $.009 *$ \\
\hline $2006-2010$ & 50 & 10908.80 & 11360.00 & 451.20 & 0.52 & -4.38 & $.000^{*}$ \\
\hline 2011 Onwards & 50 & 12224.00 & 12332.00 & 108.00 & 0.46 & -1.043 & $.302^{* *}$ \\
\hline Total & 200 & 10106.50 & 11559.50 & 1453.00 & 1.13 & -9.62 & .000 \\
\hline
\end{tabular}

**indicates insignificant at 5 per cent level; *indicates significant at 5 per cent level; Gloss: CAGR-Compound Annual Growth Rate; Source: Field survey. 
2000 were out performed compared to other groups.

Taking the period of association and the approached (non-association) wise income of the respondents into consideration, 1996-2000 groups benefited more which constituted 11.82 per cent increase in CAGR and had highest income in the post microfinance period i.e. ₹ 49961.50, which is more in worth than any other period of association. As compared to the beneficiaries, the non-beneficiaries could not achieve significant increase in the average annual income in the Malenadu region.

Thus, it is evident that the beneficiaries of microfinance have recorded a satisfactory increase in their incremental annual income as compared to the non-beneficiaries who were outside the fold of microfinance.

\section{Comparative Analysis of Saving Level of Beneficiaries and Non-Beneficiaries}

To find out the difference in savings of the beneficiaries with the non-beneficiaries of microfinance in the various periods, the total beneficiaries and non-beneficiaries were broadly classified into four groups viz., (1) 1996-2000 (2) 2001-2005 (3) 2006-2010 and (4) 2011 onwards.
Table 11: Savings Level

\begin{tabular}{ccc}
\hline $\begin{array}{c}\text { Savings/ } \\
\text { Investments }\end{array}$ & Beneficiaries & Non-Beneficiaries \\
\hline $600-1599$ & 1 & 3 \\
$1600-2599$ & 1 & 43 \\
$2600-3599$ & 1 & 62 \\
$4600-5599$ & 2 & 76 \\
$5600-6599$ & 2 & 7 \\
$6600-7599$ & 3 & 9 \\
$7600-8599$ & 11 & - \\
$8600-9599$ & 26 & - \\
$9600-10599$ & 87 & - \\
$10600-11599$ & 73 & - \\
$11600-12599$ & 72 & - \\
$12600-13599$ & 102 & - \\
$13600-14599$ & 60 & - \\
$14600-15599$ & 70 & - \\
$15600-16599$ & 66 & - \\
$16600-17599$ & 36 & - \\
$17600-18599$ & 25 & - \\
$18600-19599$ & 28 & - \\
$19600-20599$ & 38 & - \\
$20600-21599$ & 24 & - \\
$21600-22599$ & 61 & - \\
$22600-23599$ & 6 & - \\
$23600-24599$ & 4 & - \\
$24600-25599$ & 1 & \\
\hline Grand Total & 800 & \\
\hline & & \\
\hline
\end{tabular}

Source: Field Survey.

Table 12: Saving Level of Beneficiaries and Non-Beneficiaries

\begin{tabular}{|c|c|c|c|c|c|c|c|}
\hline \multicolumn{8}{|c|}{ Beneficiaries } \\
\hline $\begin{array}{l}\text { Period of } \\
\text { Association }\end{array}$ & Respondents & $\begin{array}{c}\text { Pre } \\
\text { Average Annual } \\
\text { Savings } \\
\end{array}$ & $\begin{array}{l}\text { Post Average } \\
\text { Annual Savings }\end{array}$ & $\begin{array}{l}\text { Incremental } \\
\text { Savings }\end{array}$ & CAGR \% & $\begin{array}{l}\text { Paired } \\
t \text {-value }\end{array}$ & $\begin{array}{l}\text { Sig. (2 } \\
\text { tailed) }\end{array}$ \\
\hline $1996-2000$ & 200 & 2684.40 & 23569.00 & 20884.60 & 12.98 & -34.15 & $.000^{*}$ \\
\hline 2001-2005 & 200 & 3442.20 & 18393.20 & 14951.00 & 14.92 & -45.40 & $.000^{*}$ \\
\hline $2006-2010$ & 200 & 3778.80 & 14879.80 & 11101.00 & 20.30 & -40.55 & $.000^{*}$ \\
\hline 2011 Onwards & 200 & 4308.00 & 12000.40 & 7692.40 & 32.35 & -36.65 & $.000^{*}$ \\
\hline Total & 800 & 3553.35 & 17210.60 & 13657.25 & 20.11 & -52.57 & $.000^{*}$ \\
\hline \multicolumn{8}{|c|}{ Non-Beneficiaries } \\
\hline $\begin{array}{l}\text { Approached for } \\
\text { Microfinance } \\
\text { (Non-Association) }\end{array}$ & Respondents & $\begin{array}{c}\text { Pre } \\
\text { Average Annual } \\
\text { Savings } \\
\end{array}$ & $\begin{array}{l}\text { Present Average } \\
\text { Annual Savings }\end{array}$ & $\begin{array}{l}\text { Incremental } \\
\text { Savings }\end{array}$ & CAGR \% & $\begin{array}{l}\text { Paired } \\
t \text {-value }\end{array}$ & $\begin{array}{l}\text { Sig. (2 } \\
\text { tailed) }\end{array}$ \\
\hline $1996-2000$ & 50 & 3009.90 & 4919.50 & 1909.60 & 3.14 & -41.73 & $.000^{*}$ \\
\hline 2001-2005 & 50 & 2793.00 & 2821.60 & 28.58 & 0.14 & -0.605 & $.548^{* *}$ \\
\hline 2006-2010 & 50 & 3072.64 & 3208.00 & 135.40 & 0.55 & -4.38 & $.000^{*}$ \\
\hline 2011 Onwards & 50 & 3567.20 & 3599.60 & 32.40 & 0.47 & -1.043 & $.302^{* *}$ \\
\hline Total & 200 & 3110.70 & 3637.20 & 526.50 & 1.08 & -8.778 & $.000^{*}$ \\
\hline
\end{tabular}

**indicates insignificant at 5 per cent level; *indicates significant at 5 per cent level; Gloss: CAGR-Compound Annual Growth Rate; Source: Field survey. 
Table 11 reveals the saving level of beneficiaries and non-beneficiaries during pre and post period in Malenadu region.

The $t$ values have been calculated to know the level of significance in generation of savings during post-microfinance period. The values are significant at 5 per cent level in case of beneficiaries in all period of association and it is insignificant at 5 per cent in case of non-beneficiaries for the period 2001-2005 and 2011 onwards. It is observed from the Table 12 that the incremental savings of the non-beneficiaries is comparatively less than the beneficiaries. It is noticed from the table that the savings generated with the help of microfinance is very high constituting 20.11 per cent increase as compared with the non-beneficiaries whose savings are only 1.08 per cent.

The period of association analysis during the post period shows that, beneficiaries who availed microfinance during 1996-2000 recorded the highest saving of ₹ 23569.00 , but it is just ₹ 4919.50 for the non-beneficiaries. Negligible improvement can be found in case of non-beneficiaries in which only 0.14 per cent growth in their savings is recorded during the period of 2001-2005.

Overall, it is evident that the beneficiaries of microfinance have recorded a satisfactory increase in their incremental savings as compared to the non-beneficiaries who were outside the fold of microfinance.

\section{Comparative Analysis of Food Expenditure of Beneficiaries and Non-Beneficiaries}

To find out the difference in food expenditure of the beneficiaries with the non-beneficiaries of microfinance in the various periods, the total beneficiaries and non-beneficiaries were broadly classified into four groups viz., (1) 1996-2000 (2) 2001-2005 (3) 2006-2010 and (4) 2011 onwards.

Table 13: Food Expenditure

\begin{tabular}{ccc}
\hline $\begin{array}{c}\text { No. of } \\
\text { Respondents }\end{array}$ & Beneficiaries & Non-Beneficiaries \\
\hline$<2000$ & 3 & 18 \\
$2000-4000$ & 7 & 156 \\
$4000-6000$ & 94 & 26 \\
$6000-8000$ & 208 & - \\
$8000-10000$ & 162 & - \\
$10000-12000$ & 79 & - \\
$12000-14000$ & 122 & - \\
$14000-16000$ & 45 & - \\
$16000-18000$ & 34 & - \\
$18000-20000$ & 12 & - \\
$>20000$ & 34 & - \\
\hline Grand Total & $\mathbf{8 0 0}$ & $\mathbf{2 0 0}$ \\
\hline
\end{tabular}

Source: Field Survey.

Table 14: Food Expenditure of Beneficiaries and Non-Beneficiaries

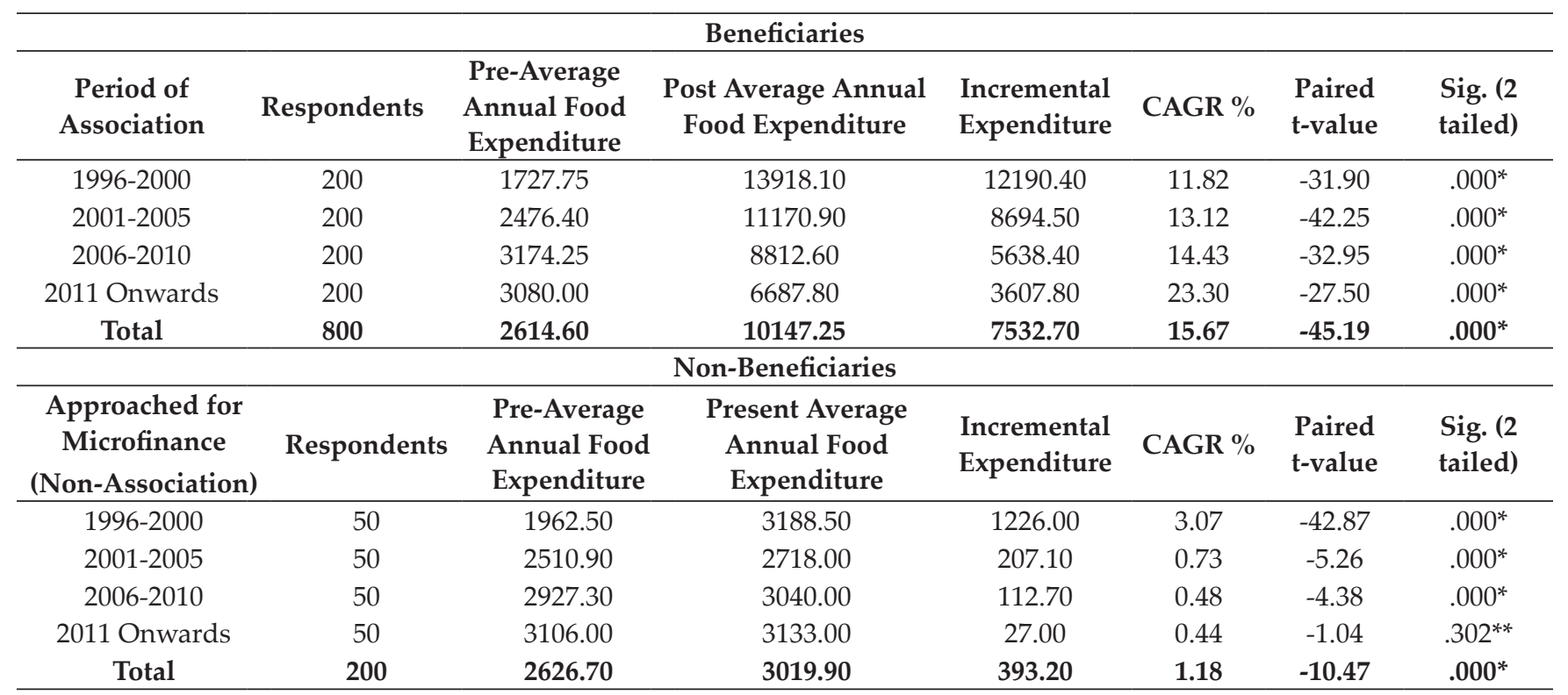

**indicates insignificant at 5 per cent level; *indicates significant at 5 per cent level; Gloss: CAGR-Compound Annual Growth Rate; Source: Field survey. 
Table 13 reveals the food expenditure of beneficiaries and non-beneficiaries pre and post period in Malenadu region.

It is observed from the Table 14 that the food expenditure incurred by the beneficiaries is high as compared to that of the non-beneficiaries. It is 15.67 per cent in beneficiaries and 1.18 per cent in nonbeneficiaries in the post period. To know how the microfinance programme influences the spending pattern of the beneficiaries ' $t$ ' tests are conducted and noted that its values are significant at 5 per cent level in case of beneficiaries in all periods of association and it is insignificant in case of nonbeneficiaries in the period 2011 onwards.

Period of association and approached (nonassociation) analysis shows that the food expenditure incurred by all period is more or less same during pre and post period in the case of non-beneficiaries, but a remarkable change is found in case of beneficiaries. Period of association analysis shows that, beneficiaries who availed microfinance during 1996-2000 recorded the highest spending of ₹ 13918.10 , but it is just ₹ 3188.50 during the post period for the non-beneficiaries. Negligible improvement can be found in case of non-beneficiaries in which the non-client from 2011 onwards period recorded only 0.44 per cent growth in their spending.
Overall, it is evident that the beneficiaries of microfinance have recorded a satisfactory increase in their incremental food expenditure as compared to the non-beneficiaries. This shows affordability of beneficiaries is much higher than non-beneficiaries.

\section{Comparative Analysis of Personal Expenditure of Beneficiaries and Non-Beneficiaries}

To find out the difference in personal expenditure of the beneficiaries with the non-beneficiaries of microfinance in the various periods, the total beneficiaries and non-beneficiaries were broadly classified into four groups viz., (1) 1996-2000 (2) 2001-2005 (3) 2006-2010 and (4) 2011 onwards.

Table 15: Personal Expenditure

\begin{tabular}{ccc}
\hline Scales & Beneficiaries & Non-Beneficiaries \\
\hline $200-1200$ & 38 & 52 \\
$1200-2200$ & 449 & 72 \\
$2200-3200$ & 183 & 66 \\
$>3200$ & 130 & 10 \\
Grand & 800 & 200 \\
Total & & \\
\hline
\end{tabular}

Source: Field Survey.

Table 15 reveals the personal expenditure of beneficiaries and non-beneficiaries pre and post period in Malenadu region.

Table 16: Personal Expenditure of Beneficiaries and Non-Beneficiaries

\begin{tabular}{|c|c|c|c|c|c|c|c|}
\hline \multicolumn{8}{|c|}{ Beneficiaries } \\
\hline $\begin{array}{c}\text { Period of } \\
\text { Association }\end{array}$ & Respondents & $\begin{array}{c}\text { Pre-Average } \\
\text { Annual Personal } \\
\text { expenditure }\end{array}$ & $\begin{array}{c}\text { Post Average } \\
\text { Annual Personal } \\
\text { expenditure }\end{array}$ & $\begin{array}{c}\text { Incremental } \\
\text { Personal } \\
\text { expenditure }\end{array}$ & CAGR \% & $\begin{array}{l}\text { Paired } \\
\text { t-value }\end{array}$ & $\begin{array}{l}\text { Sig. (2 } \\
\text { tailed) }\end{array}$ \\
\hline $1996-2000$ & 200 & 785.55 & 3133.60 & 2348.10 & 7.83 & -30.72 & $.000^{*}$ \\
\hline 2001-2005 & 200 & 505.30 & 2374.30 & 1869.00 & 13.50 & -45.41 & $.000^{*}$ \\
\hline 2006-2010 & 200 & 434.85 & 1922.70 & 1487.90 & 22.36 & -43.48 & $.000^{*}$ \\
\hline \multicolumn{8}{|c|}{ Non-Beneficiaries } \\
\hline $\begin{array}{l}\text { Approached for } \\
\text { Microfinance } \\
\text { (Non-Association) }\end{array}$ & Respondents & $\begin{array}{c}\text { Pre-Average } \\
\text { Annual Personal } \\
\text { expenditure }\end{array}$ & $\begin{array}{c}\text { Present Average } \\
\text { Annual Personal } \\
\text { expenditure }\end{array}$ & $\begin{array}{c}\text { Incremental } \\
\text { Personal } \\
\text { expenditure }\end{array}$ & CAGR \% & $\begin{array}{l}\text { Paired } \\
\text { t-value }\end{array}$ & $\begin{array}{l}\text { Sig. (2 } \\
\text { tailed) }\end{array}$ \\
\hline Total & 200 & 1735.70 & 1842.90 & 107.20 & 1.20 & -8.90 & $.000^{*}$ \\
\hline
\end{tabular}

**indicates insignificant at 5 per cent level; *indicates significant at 5 per cent level; Gloss: CAGR-Compound Annual Growth Rate; Source: Field survey. 
To know how the microfinance programme influences the spending pattern of the beneficiaries ' $t$ ' tests are conducted and noted that its values are significant at 5 per cent level in case of beneficiaries in all periods of association and it is insignificant in case of non-beneficiaries in the period 2011 onwards. It is observed from the Table 16 that the personal expenditure incurred by the beneficiaries is comparatively high with the non-beneficiaries. It is 13.19 per cent in beneficiaries and 1.20 per cent in non-beneficiaries in the post period.

The period of association and approached (nonassociation) analysis shows that the personal expenditure incurred by all period is more or less same during pre and post period in the case of nonbeneficiaries, but a remarkable change is found in case of beneficiaries. Period of association analysis shows that, beneficiaries who availed microfinance during 1996-2000 recorded the highest spending of ₹ 3133.60 , but it is just $₹ 568.70$ during the post period for the non-beneficiaries. Negligible improvement can be found in case of non-beneficiaries in which the non-client from 2001-2005 periods recorded only 0.40 per cent growth in their spending.

It is evident that the beneficiaries of microfinance have recorded a satisfactory increase in their incremental personal expenditure as compared to the non-beneficiaries. This shows degree of freedom for spending and affordability of beneficiaries is much higher than non-beneficiaries.

\section{Comparative Analysis of Expenditure on Purchase of Home Appliances by the Beneficiaries and Non-Beneficiaries}

To find out the difference in expenditure on Purchase of Home Appliances by the beneficiaries with the non-beneficiaries of microfinance in the various periods, the total beneficiaries and nonbeneficiaries were broadly classified into four groups viz., (1) 1996-2000 (2) 2001-2005 (3) 2006-2010 and (4) 2011 onwards.

Table 17: Home Appliances

\begin{tabular}{ccc}
\hline Scales & Beneficiaries & Non-Beneficiaries \\
$<1250$ & 2 & 113 \\
$1250-2250$ & 4 & 76 \\
$2250-3250$ & 63 & 11 \\
$3250-4250$ & 130 & - \\
$4250-5250$ & 180 & - \\
$5250-6250$ & 118 & - \\
$6250-7250$ & 67 & - \\
$7250-8250$ & 77 & - \\
$8250-9250$ & 58 & - \\
$9250-10250$ & 27 & - \\
$>10250$ & 74 & - \\
Grand Total & $\mathbf{8 0 0}$ & $\mathbf{2 0 0}$ \\
\hline
\end{tabular}

Source: Field Survey.

Table 18: Purchase of Home Appliances by the Beneficiaries and Non-Beneficiaries

\begin{tabular}{|c|c|c|c|c|c|c|c|}
\hline \multicolumn{8}{|c|}{ Beneficiaries } \\
\hline $\begin{array}{c}\text { Period of } \\
\text { Association }\end{array}$ & Respondents & $\begin{array}{c}\text { Pre-Average Annual } \\
\text { Expenditure on } \\
\text { Home Appliances }\end{array}$ & $\begin{array}{l}\text { Post Average Annual } \\
\text { Expenditure on } \\
\text { Home Appliances }\end{array}$ & $\begin{array}{c}\text { Incremental } \\
\text { Expenditure on } \\
\text { Home Appliances }\end{array}$ & $\begin{array}{c}\text { CAGR } \\
\%\end{array}$ & $\begin{array}{l}\text { Paired } \\
\text { t-value }\end{array}$ & $\begin{array}{l}\text { Sig. (2 } \\
\text { tailed) }\end{array}$ \\
\hline $1996-2000$ & 200 & 1056.70 & 8950.90 & 7894.20 & 12.74 & -34.43 & $.000^{*}$ \\
\hline 2001-2005 & 200 & 1315.80 & 6422.60 & 5106.80 & 14.01 & -41.36 & $.000^{*}$ \\
\hline 2006-2010 & 200 & 1554.60 & 5397.70 & 3843.10 & 18.13 & -37.44 & $.000^{*}$ \\
\hline 2011 Onwards & 200 & 1703.00 & 4012.70 & 2309.70 & 26.25 & -29.34 & $.000^{*}$ \\
\hline Total & 800 & 1407.50 & 6195.90 & 4788.40 & 17.78 & -46.69 & $.000^{*}$ \\
\hline \multicolumn{8}{|c|}{ Non-Beneficiaries } \\
\hline $\begin{array}{l}\text { Approached for } \\
\text { Microfinance } \\
\text { (Non-Association) }\end{array}$ & $\begin{array}{l}\text { Respondents } \\
\text { ) }\end{array}$ & $\begin{array}{c}\text { Pre-Average Annual } \\
\text { Expenditure on } \\
\text { Home Appliances }\end{array}$ & $\begin{array}{c}\text { Present Average } \\
\text { Annual Expenditure } \\
\text { on Home Appliances }\end{array}$ & $\begin{array}{c}\text { Incremental } \\
\text { Expenditure on } \\
\text { Home Appliances }\end{array}$ & $\begin{array}{c}\text { CAGR } \\
\%\end{array}$ & $\begin{array}{l}\text { Paired } \\
\text { t-value }\end{array}$ & $\begin{array}{l}\text { Sig. (2 } \\
\text { tailed) }\end{array}$ \\
\hline $1996-2000$ & 50 & 1097.50 & 1771.10 & 673.60 & 3.07 & -39.26 & $.000^{*}$ \\
\hline 2001-2005 & 50 & 764.00 & 807.00 & 43.00 & 0.57 & -4.20 & $.000^{*}$ \\
\hline 2006-2010 & 50 & 890.90 & 936.00 & 45.10 & .63 & -4.38 & $.000^{*}$ \\
\hline 2011 Onwards & 50 & 1272.40 & 1283.20 & 10.80 & 0.43 & -1.043 & $.302^{* *}$ \\
\hline Total & 200 & 1006.30 & 1199.40 & 193.10 & 1.18 & -9.26 & $.000^{*}$ \\
\hline
\end{tabular}

**indicates insignificant at 5 per cent level; *indicates significant at 5 per cent level; Gloss: CAGR-Compound Annual Growth Rate; Source: Field survey. 
Table 17 reveals the expenditure on Purchase of Home Appliances by the beneficiaries and nonbeneficiaries pre and post period in Malenadu region.

It is observed from the Table 18 that the expenditure incurred by the beneficiaries is comparatively high with the non-beneficiaries. It is 17.78 per cent in beneficiaries and 1.18 per cent in non-beneficiaries in the post period. To know how the microfinance programme influences the spending pattern of the beneficiaries $t$ tests are conducted and noted that its values are significant at 5 per cent level in case of beneficiaries in all periods of association and it is insignificant in case of non-beneficiaries in the period 2011 onwards.

The period of association and approached (nonassociation) analysis shows that the expenditure incurred by all period is more or less same during pre and post period in the case of non-beneficiaries, but a remarkable change is found in case of beneficiaries. Period of association analysis shows that, beneficiaries who availed microfinance during 1996-2000 recorded the highest spending of ₹ 8950.90 , but it is just $₹ 1771.10$ during the post period for the non-beneficiaries. Negligible improvement can be found in case of non-beneficiaries in which the non-client from 2011 periods onwards recorded only 0.43 per cent growth in their spending.

On the whole, it is evident that the beneficiaries of microfinance have recorded a satisfactory increase in their incremental expenditure on home appliances as compared to the non-beneficiaries. This shows affordability of beneficiaries is much higher than the non-beneficiaries.

\section{Comparative Analysis of Investment on Fixed Assets and Livestock by the Beneficiaries and Non-Beneficiaries}

To find out the difference in Investment on Fixed Assets and Livestock by the beneficiaries with the non-beneficiaries of microfinance in the various periods, the total beneficiaries and non-beneficiaries were broadly classified into four groups viz., (1) 1996-2000 (2) 2001-2005 (3) 2006-2010 and (4) 2011 onwards.

Table 19: Fixed and Livestock

\begin{tabular}{ccc}
\hline Scales & Before Microfinance & After Microfinance \\
\hline $190-1189$ & 359 & 3 \\
$1190-2189$ & 431 & 9 \\
$2190-3189$ & 9 & 91 \\
$3190-4189$ & - & 205 \\
$4190-5189$ & - & 174 \\
$5190-6189$ & - & 95 \\
$6190-7189$ & - & 104 \\
$7190-8189$ & 1 & 50 \\
$>8190$ & - & 69 \\
Grand Total & $\mathbf{8 0 0}$ & $\mathbf{8 0 0}$ \\
\hline
\end{tabular}

Source: Field Survey.

Table 20: Investment on Fixed Assets and Livestock by the Beneficiaries and Non-Beneficiaries

\begin{tabular}{|c|c|c|c|c|c|c|c|}
\hline \multicolumn{8}{|c|}{ Beneficiaries } \\
\hline $\begin{array}{c}\text { Period of } \\
\text { Association }\end{array}$ & Respondents & $\begin{array}{c}\text { Pre-Average Annual } \\
\text { Investment on } \\
\text { Assets } \\
\end{array}$ & $\begin{array}{c}\text { Post Average } \\
\text { Annual Investment } \\
\text { on Assets }\end{array}$ & $\begin{array}{c}\text { Incremental } \\
\text { Investment on } \\
\text { Assets } \\
\end{array}$ & $\begin{array}{c}\text { CAGR } \\
\%\end{array}$ & $\begin{array}{l}\text { Paired } \\
\text { t-value }\end{array}$ & $\begin{array}{l}\text { Sig. (2 } \\
\text { tailed) }\end{array}$ \\
\hline $1996-2000$ & 200 & 1125.30 & 6620.70 & 5495.40 & 9.25 & -29.96 & $.000^{*}$ \\
\hline 2001-2005 & 200 & 1042.70 & 5858.00 & 4815.30 & 15.39 & -48.74 & $.000^{*}$ \\
\hline 2006-2010 & 200 & 1383.60 & 4443.90 & 3060.30 & 16.80 & -37.26 & $.000^{*}$ \\
\hline \multicolumn{8}{|c|}{ Non-Beneficiaries } \\
\hline $\begin{array}{l}\text { Approached for } \\
\text { Microfinance } \\
\text { (Non-Association) }\end{array}$ & Respondents & $\begin{array}{c}\text { Pre-Average Annual } \\
\text { Investment on } \\
\text { Assets }\end{array}$ & $\begin{array}{c}\text { Present Average } \\
\text { Annual Investment } \\
\text { on Assets }\end{array}$ & $\begin{array}{c}\text { Incremental } \\
\text { Investment on } \\
\text { Assets }\end{array}$ & CAGR \% & $\begin{array}{l}\text { Paired } \\
\text { t-value }\end{array}$ & $\begin{array}{l}\text { Sig. (2 } \\
\text { tailed) }\end{array}$ \\
\hline Total & 200 & 928.10 & 1102.60 & 174.50 & 1.08 & -9.04 & $.000^{*}$ \\
\hline
\end{tabular}

**indicates insignificant at 5 per cent level; *indicates significant at 5 per cent level; Gloss: CAGR-Compound Annual Growth Rate; Source: Field survey. 
Table 19 reveals the Investment on fixed assets and livestock by the beneficiaries and non-beneficiaries pre and post period in Malenadu region.

The calculated ' $t$ ' values shows that the asset creation in beneficiaries are significant ion all periods of association, but it is insignificant in nonbeneficiaries in period 2011 onwards. It is evident from Table 20 that comparatively the asset creation in case of beneficiaries is the highest of 17.11 per cent, as against the non-beneficiaries whose percentage is just 1.08 per cent only. The period of association and approached (non-association) analysis shows that the Investment on fixed assets and livestock by all period is more or less same during pre and post period in the case of nonbeneficiaries, but a remarkable change is found in case of beneficiaries. Period of association analysis shows that, beneficiaries who availed microfinance during 1996-2000 recorded the highest Investment on fixed assets and livestock of ₹ 5495.40, but it is just ₹ 628.90 during the post period for the nonbeneficiaries. Negligible improvement can be found in case of non-beneficiaries in which the non-client from 2001-2005 periods recorded only 0.31 per cent growth in their investment.

Acquisition of assets is an indication of capital formation and also improvement in the living standards of clients. Availability of credit played an important role in the acquisition of assets. The proportion of sample client acquiring assets with microfinance support is increased by 17.11 per cent.

\section{Comparative Analysis of Educational Expenditure of Beneficiaries and Non- Beneficiaries}

To find out the difference in Educational Expenditure ofthe beneficiaries with the non-beneficiaries of microfinance in the various periods, the total beneficiaries and non-beneficiaries were broadly classified into four groups viz., (1) 1996-2000 (2) 2001-2005 (3) 2006-2010 and (4) 2011 onwards.

Table 21: Educational Expenditure

\begin{tabular}{ccc}
\hline Scales & Beneficiaries & Non-Beneficiaries \\
\hline$<190$ & 7 & - \\
$190-690$ & 121 & 89 \\
$690-1190$ & 382 & 90 \\
$1190-1690$ & 181 & 21 \\
$1690-2190$ & 75 & - \\
$2190-2690$ & 33 & - \\
$2690-3190$ & 1 & - \\
Grand Total & 800 & 200 \\
\hline
\end{tabular}

Source: Field Survey.

Table 21 reveals the Educational expenditure of beneficiaries and non-beneficiaries pre and post period in Malenadu region.

Table 22: Educational Expenditure of Beneficiaries and Non-Beneficiaries

\begin{tabular}{|c|c|c|c|c|c|c|c|}
\hline \multicolumn{8}{|c|}{ Beneficiaries } \\
\hline $\begin{array}{c}\text { Period of } \\
\text { Association }\end{array}$ & Respondents & $\begin{array}{c}\text { Pre-Average } \\
\text { Annual Educational } \\
\text { Expenditure }\end{array}$ & $\begin{array}{c}\text { Post Average } \\
\text { Annual Educational } \\
\text { Expenditure }\end{array}$ & $\begin{array}{l}\text { Incremental } \\
\text { Educational } \\
\text { Expenditure }\end{array}$ & CAGR \% & $\begin{array}{l}\text { Paired } \\
\text { t-value }\end{array}$ & $\begin{array}{l}\text { Sig. (2 } \\
\text { tailed) }\end{array}$ \\
\hline $1996-2000$ & 200 & 331.30 & 1480.20 & 1148.90 & 5.37 & -25.05 & $.000^{*}$ \\
\hline 2001-2005 & 200 & 323.20 & 1264.60 & 941.40 & 11.71 & -38.13 & $.000^{*}$ \\
\hline 2006-2010 & 200 & 370.90 & 993.70 & 622.80 & 13.87 & -30.34 & $.000^{*}$ \\
\hline 2011 Onwards & 200 & 285.60 & 762.60 & 477.00 & 31.27 & -30.30 & $.000^{*}$ \\
\hline Total & 800 & 327.75 & 1125.20 & 797.40 & 15.56 & -46.24 & $.000^{*}$ \\
\hline \multicolumn{8}{|c|}{ Non-Beneficiaries } \\
\hline $\begin{array}{l}\text { Approached for } \\
\text { Microfinance } \\
\text { (Non-Association) }\end{array}$ & Respondents & $\begin{array}{c}\text { Pre-Average } \\
\text { Annual Educational } \\
\text { Expenditure }\end{array}$ & $\begin{array}{c}\text { Present Average } \\
\text { Annual Educational } \\
\text { Expenditure }\end{array}$ & $\begin{array}{l}\text { Incremental } \\
\text { Educational } \\
\text { Expenditure }\end{array}$ & CAGR \% & $\begin{array}{l}\text { Paired } \\
\text { t-value }\end{array}$ & $\begin{array}{l}\text { Sig. (2 } \\
\text { tailed) }\end{array}$ \\
\hline $1996-2000$ & 50 & 274.50 & 429.20 & 154.70 & 2.77 & -45.09 & $.000^{*}$ \\
\hline 2001-2005 & 50 & 671.50 & 705.80 & 34.30 & 0.51 & -2.72 & $.009^{*}$ \\
\hline 2006-2010 & 50 & 972.70 & 1008.80 & 36.10 & 0.46 & -4.38 & $.000^{*}$ \\
\hline 2011 Onwards & 50 & 877.90 & 886.60 & 8.70 & 0.54 & -1.04 & $.302^{* *}$ \\
\hline Total & 200 & 699.10 & 757.60 & 58.50 & 1.07 & -9.88 & $.000 *$ \\
\hline
\end{tabular}

**indicates insignificant at 5 per cent level; *indicates significant at 5 per cent level; Gloss: CAGR-Compound Annual Growth Rate; Source: Field survey. 
To know how the microfinance programme influences the spending pattern of the beneficiaries ' $t$ ' tests are conducted and noted that its values are significant at 5 per cent level in case of beneficiaries in all periods of association and it is insignificant in case of non-beneficiaries in the period 2011 onwards. It is observed from the Table 22 that the Educational expenditure incurred by the beneficiaries is comparatively high with the non-beneficiaries. It is $\mathbf{1 5 . 5 6}$ per cent in beneficiaries and 1.07 per cent in non-beneficiaries in the post period. The period of association and approached (non-association) analysis shows that the Educational expenditure incurred by all period is more or less same during pre and post period in the case of non-beneficiaries, but a remarkable change is found in case of beneficiaries. Period of association analysis shows that, beneficiaries who availed microfinance during 1996-2000 recorded the highest spending of ₹ 1480.20 , but it is just $₹ 429.20$ during the post period for the non-beneficiaries. Negligible improvement can be found in case of non-beneficiaries in which the non-client from 2006-2010 periods recorded only 0.46 per cent growth in their spending.

On the whole, it is evident that the beneficiaries of microfinance have recorded a satisfactory increase in their incremental Educational expenditure as compared to the non-beneficiaries. This shows affordability of beneficiaries is much higher than non-beneficiaries.

\section{CONCLUSION}

The SHG can contribute to changes in economic conditions, social status, decision making and increases women in outdoor activities. SHG not only changes the outer form of a community or a society, but also the social institutions as well as ideas of the people living in the society.

\section{RECOMMENDATIONS}

Based on the finding made during the course of study, the following suggestions are made for further improvement in the performance of SHGs and for the upliftment of women socially and economically.

(a) Government can take necessary steps to sell the SHG products through civil supplies, for example, good products may be sold in ration shops and agricultural depots. (b) Banks have to conduct the SHGs training at every Panchayat level, which will be convenient to attend by the members of SHGs at their local place.

(c) Women's were underpaid for equal work; women were locked in low-paid jobs; stereotypes determine the appropriate roles for women in the economy; women lack access to markets for inputs and outputs if their mobility is constrained due to social norms. Government should come with a special policy to create a separate cell for solving problems of Women SHG.

(d) Agriculture is the predominant sector for microfinance beneficiaries of the Malenadu region, which employs nearly 47.125 per cent of the total respondents. Thus, from a risk point of view, we need to recognize that there is a subtle difference between microfinance for agriculture and microfinance for the agricultural operations of poor households with diversified sources of income.

(e) The banks need not insist on the members to submit 'No Dues' certificate in order to get new loans. Instead, they may go by taking into account the nature of activity and the progress of the group.

(f) Self-Help Group should not only concentrate on the growth of the group, but should also show active involvement on the social issues and other essential issues like health, sanitation etc. to develop the entire village.

(g) Block and bank officials should make surprise and frequent visit to the respondents to ensure the proper utilization of bank loan on various economic activities.

(h) To make micro financing a success story we should switch over to the "Islamic Banking Model" which emphasis on zero per cent rate of interest. Instead of disbursing crores of rupees in subsidies to the beneficiaries of the microfinance, the government should compensate the financing institutions with this subsidy amount so that they can provide loans at zero per cent rate of interest. This will reduce the risk of mis-utilization of loan and will subsequently help to reduce nonperforming assets in the banks. 
(i) There is a serious need to introduce micro insurance products and bring together various players in the insurance sector for supporting pilots for development of composite insurance products, which cater for life, health, crops, assets and accidents.

(j) Banks who thoroughly track those who choose to leave the program are most likely to identify and address problems clients have with the Banks services. They may conduct regular surveys of clients' satisfaction.

\section{REFERENCES}

Angel. A Anila, 2012. A Study On Socio-Economic Condition Of Self Help Group Members In Tirunelveli District, Tamil Nadu ZENITH International Journal of Business Economics \& Management Research, 2(2): 216-224.

Asad Kamran Ghalib, 2009. Impact Assessment Research Centre (IARC), University Of Manchester, IARC Working Papers Series No. 24/2009.

Morduch, J. and Haley, B. 2001. Analysis of the Effects of Microfinance on Poverty Reduction, CIDA, Ottawa.
Mula G. and Sarker, S.C. 2013. Impact of microfinance on women empowerment: An economic analysis from Eastern India, African Journal of Agricultural Research, 8(45): 5673-5684.

Nasim Shah Shirazi, 2012. Targeting and Socio-Economic Impact of Microfinance: A Case Study of Pakistan, Islamic Economic Studies, 20(2): 1-28.

Rao, Mamta 2008. Law relating to women and children (3rd ed.). Lucknow: Eastern Book Co. ISBN 9788170121329. women and the protection provided under various criminal, personal and labour laws in India.

Reji, E.M. 2009. Socio-Economic Impact of Microfinance: A Study of Neighbourhood Groups (NHGs) in Nilambur Block of Malappuram District, Kerala, Indian Journal of Agricultural Economics, 64(2): 246 - 258.

Sivachithappa, K. 2013. Impact of Micro Finance on Income Generation and Livelihood of Members of Self Help Groups - A Case Study of Mandya District, India, ProcediaSocial and Behavioral Sciences, 91: 228 - 240.

Yasmine F. Nader, 2008. Microcredit and the socio-economic wellbeing of women and their families in Cairo, The Journal of Socio-Economics, 37: 644-656. 